\title{
POLITICAL ECONOMY OF RELIGIOUS AND CULTURAL SYMBOLS IN THE SOAP OPERA OF TUKANG BUBUR NAIK HAJI AT RCTI
}

\author{
Yasir \\ Faculty of Social and Political Science (FISIP) of Riau University \\ (yasirjufri@gmail.com)
}

\begin{abstract}
Television is a very influential media and important tool in capital accumulation. This study aims to reveal the use of Islamic and Betawi ethnic symbols, workers, and also the audiences of Tukang Bubur Naik Haji (TBNH) soap opera at RCTI. This research used a political economy of communication perspective. The data were collected by using interview, observation, documentation, and literature study. The result shows that the religious symbols of Islam and Betawi culture have been exploited as comodity to be traded. Those symbols have been commercialized dan manipulated through the use of sensational, provocative, and hyperbole words or sentences to entertain audiences and to attract the advertisers. The hyper-comercialization and politicization of symbols caused the soap opera workers and Moslem audiences have been exploited.

Televisi adalah media yang sangat berpengaruh dan juga alat yang penting dalam mengakumulasi modal. Tulisan ini bertujuan untuk mengungkap pemanfaatan simbol agama Islam dan budaya Betawi, pekerja sinetron dan khalayak sinetron Tukang Bubur Naik Haji (TBNH) di RCTI. Penelitian ini menggunakan pendekatan ekonomi politik komunikasi. Untuk mengumpulkan data peneliti melakukan wawancara mendalam, observasi, dokumentasi dan studi literatur. Hasil penelitian menunjukkan bahwa simbol agama dan budaya Betawi dieksploitasi sebagai komoditas untuk diperjualbelikan. Simbol tersebut dikomersialisasi dan diselewengkan melalui penggunaan kata-kata dan kalimat serta tayangan yang sensasional, provokatif dan hiperbola untuk menghibur dan menarik khalayak. Hiper-komersialisasi dan politisasi simbol ini menyebabkan pekerja sinetron dan khalayak muslim ikut dikomodifikasi dan dieksploitasi.
\end{abstract}

Keywords: political economy of communication, exploitation, comodity, religious symbols, soap opera. 


\section{A. Introduction}

Television is a business. Television is also a very important tool to accumulate capital. Nixon reveals that the centralized and accumulated capital through the communication process is communicative capital ${ }^{1}$. In Indonesia, many conglomerates are trying to integrate their business with the communication field such as: Hary Tanoesoedibjo (MNC Group), Chaerul Tanjung (CT Corp), Mochtar and James Riady (Lippo Group), Jacob Utama (Kompas Gramedia Group), Sariatmaja (Elang Mahkota Tekonologi / EMTEK), and others.

Currently television is still the main medium of entertainment or information for the public. Nielsen says that advertisement expenditure on television in 2013 amounted $\mathrm{Rp} 73$ trillion, with a share of $68 \%$ from the total $\mathrm{Rp} 106$ trillion $^{2}$. This suggests that the television industry attracted public attention through its various programs. It indicates that television is still the main medium in the advertising industry. Among many television programs, electronic cinema (soap opera) is the most popular. Soap opera is also as excellent television program for some certain television stations dominating for achieving high rating. Soap opera is also the most dominated programs on some televisions such as RCTI, SCTV, MNCTV, ANTV, TransTV and Indosiar.

One of the soap opera targeted to the Islamic society is religious soap opera genre. This soap opera is generally packaged and supported with Betawi culture or symbols. Religious soap opera appeared on national television along with other soap operas with mystical television program (horror movie) as trends in the early 2000s. The commodified Islamic symbols in this soap opera has followed the requests of the market, such as: Rahasia Ilahi \& Takdir Ilahi (TPI), Kuasa Ilahi (SCTV), Titipan Ilahi (Indosiar) and many others. The use of religious and cultural symbols is related to the potensial market of Muslim audience, even these programs become excellent program in every month of Ramadhan. The early emergence of religious soap opera tended to be more mystical. But this mystical religious soap opera hasbeen shifted and changed to be religious soap opera that tells the story of dailylife, such as: Kiamat Sudah Dekat (SCTV), Para Pencari Tuhan (SCTV), Munajah Cinta (RCTI), Ketika Cinta Bertasbih (RCTI) and others. The change will occur continually where in it is just a cover for the television industry to follow the market trends in attracting audiences.

The religious symbols were commercialized to obtain the high ratings and to accumulate capital as much as possible as the main goal. Syahputra's research showed that religious symbolism basically serve two sectors

\footnotetext{
${ }^{1}$ Brice Nixon. "Toward a Political Economy of 'Audience Labour' in Digital Era”.Triple-C: Journal for Global Sustainable Information Society: 12 (2). 2014, 725.

${ }^{2}$ Newsletter Nielsen, January 2014.
} 
simultaneously ${ }^{3}$. First, it serves audiences symbolic religious satisfaction. By using religious symbols, religiosity audience invited and even forced to get involved. The coercion took place smoothly through symbolic seduction. Second, religious symbolism serve market advertisers. The advertiser actually did not take part in using religious symbols. However, through using Islamic religious symbols, television reached more number of audiences.

Gokariksel \& McLearny adds that "Islam" has helped for creating new cultural industries and new markets for commodities, media, advertising, business and consumer segmentation ${ }^{4}$. Religious soap opera packed with other elements, such as drama, love and comedy would be a promising business. This soap opera arised because of the trend. This commodity attracts Indonesian community appealingfunny and entertainment.

The soap opera of Tukang Bubur Naik Haji(TBNH) is produced by SinemaArt production house. The soap opera was first aired on Monday, May 28, 2012 and now (June 2015) has reached over 1600 episodes. Besides getting the award for the longest soap opera from the Indonesian Record Museum (MURI), italso got awardsfrom Panasonic Gobel Award (PGA) and the International Drama Festival in Tokyo in 2014 for the category of best foreign drama. The Tokyo International Drama festival only awarded this soap opera in the ability of marketing and selling rather than the quality or artistic events of the drama that was nominated ${ }^{5}$.

The success of this soap opera is inseparable from the strategy of utilization of the religious symbols and Betawi culture simultaneously. This success also involved both artists and crew who worked behind the scenes as well as the audience as a major production factor. The excessive commodification of symbols and labor have created the process of exploitation. Because exploitation is an integral part of the capitalist labor process to accumulate capital continually.

The aim of this paper is to reveal the forms of exploitation of Islamic and Betawi symbols that involved the workers and TBNH audiences. To uncover this issue, the writer used a critical approach and the political economy of communication theory ${ }^{6}$. The techniques of collecting data were interview, documentation, literature studies and also observations.

\footnotetext{
${ }^{3}$ Iswandi Syahputra. Rahasia Simulasi Mistik Televisi. (Yogyakarta: Pustaka Pelajar, 2011) p. 334.

${ }^{4}$ Banu Gokariksel \& Ellen McLearny, "Muslim Woman, Consumer Capitalism and the Islamic Culture Industry", Journal of Middle East Woman's Studies, Volume 6, Number 3.2010, 1.

${ }^{5}$ See: www.merdeka.com, accessibleOctober 24, 2014.

${ }^{6}$ Vincent Mosco. The Political Economy of Communication, Second Edition.(New York: Sage Publication.2009), p.11.
} 


\section{B. The Working Systems of Television and Rating Dominantion}

Television generally operates-production, distribution and consumption - within the capitalistic framework. In the capitalist system, the main orientation is the profit (money). Therefore, the guideline of television is rating. Because rating program becomes very important for managers of commercial broadcasting stations to get the advertisements. Rating also always become an indicator whether the program has audience or not. The rating also becomes a concern of advertisers who want to promote their products or services ${ }^{7}$. Therefore, television industry is running very tight, fast and dynamic. Each of these television stations make various efforts and strategies to win the competition. RCTI as television station integrated with the MNC group has wide and spacious excellences and ability for penetration. This is supported by the program strategy with focus on soap operas andwomen as the primary segmentation.

Before mid of 2014, the trend of religious soap opera with Betawi cultural background was very dominant, such as TBNH, Pasmina Aiysah, dan Anak-anak Manusia at RCTI and Emak Ijah Pengen Ke Mekkah, Ustadz Fotocopi, Islam KTP, dan Para Pencari Tuhan at SCTV.This soap opera trend decreased since the mid of 2014. The soap operas has been very diverse, and even ANTV has been more reliant on imported products such as soap operas from India (Mahabharata, Ramayana, Jodha Akbar, etc.), Turkey (King of Sulaiman), and others. To face this competition, MNC group's policies and RCTI still remain focused on the TBNH soap opera that is targeted to Muslim women. RCTI also relys on the products of MNC Pictures such as Pereman Pensiun \& Tukang Ojek Pengkolan and the imported soap opera from South Korea. Related to the policy focusing on the soap opera and women, MNC's annual report in 2013 revealed:

"Especially for MNC'sprime time slot still focuseson broadcasting drama series that can attract the attention of female audiences. It is important for the company to be able to produce the right content for female audiences, because it will attract the attention of advertisers and increase the revenue. MNC will also continue to work closely with the two best production house in Indonesia, namely SinemArt and MD Entertainment to produce high-quality drama series"8.

Various efforts and strategies were made by MNC to distribute the soap opera in order to attract as many viewers as possible. MNC collaborates with the well-known production house like Sinemart for RCTI and MD Entertainment for MNCTV. TBNH soap opera program was addressed to the main segmentation of RCTI including women and Islamic societies. Women as

\footnotetext{
${ }^{7}$ Morisan.Manajemen Media Penyiaran.(Jakarta: Kencana, 2008),h $\backslash$ p.342.

${ }^{8}$ MNC Anual Report 2013.
} 
main segementation is intended in order that the company can improve the precision of the determination of the target ${ }^{9}$. RCTI has a very close relationship with the production house of Sinemart, as a major supplier in the soap opera industry. Related to this, RCTI Programing Manager argued:

"... Sinemart is still the best in terms of quality. Due to supply to the TV was not only the quality, but also the strength and reliability. If we compared to other production houses, Sinemart is very reliable. Naturally, the television always needs programs everyday covering five hours per day from $5 \mathrm{pm}$ to $11 \mathrm{pm}$. Not all PH (production house) can supply the products with the long time. So, why we do a lot of collaboration with Sinemart, because their quality is not only maintained but also they can deliver based on our demand"10.

Soap opera production involved many people. Therefore RCTI was more interested int aking a shortcut by buying program from Sinemart. Sinemart did not use workers as permanent employees, but only contract workers (seasonal). The big amount of the advertising pie contested in the television industry made the employees of RCTI and the soap operas workers (actresses and production crews) had to work hard in winning the competition. The strict pressure of television industry always forced the media workers to evaluate their work based on the rating everyday.

As an instrument of capitalist industry, television had a lot of dynamics in the production system. In this case, Sudibyo explains that what and how the programs that must be produced is determined by its correlation with the demands of advertisers and audience tastes. Because media system is commercial oriented (capitalist), then the media should have the principle where in "media content must deliver what is desired by the audience"11. The desires of the audience itself has always been based on marketing research and audience rating of television program. AGB Nielsen Indonesia is the only institution that become the reference of television for measuring the audience rating.

\section{The Characteristics of Soap Opera Industry}

Soap opera has highly colored the television industry in Indonesia. Since soap opera is very influential, almost all existing television have broadcasted various forms of soap opera. The high cost of production of soap operas does not preclude $\mathrm{PH}$ and broadcasters to continue producing and airing

${ }^{9}$ Asti Musman\& Sugeng WA.Marketing Media Penyiaran: Bukan Sekedar Jual Kecap.(Yogyakarta:CahayaAtma Putaka. 2011), h \p. 24.

${ }^{10} \mathrm{FK}$, Interview, October 15, 2014.

${ }^{11}$ Agus Sudibyo. Ekonomi Politik Media Penyiaran.(Yogyakarta: LKiS.2004), p. $62-63$. 
it. For television stations, it is no problem for buying an expensive or inexpensive program because the important thing is to sell well. Meanwhile, fort he PH, the programs have to be produced in the low cost butit can be purchased expensively ${ }^{12}$. Purchasing patterns are very diverse based on the agreement between the production house $(\mathrm{PH})$ and the television stations. There are three patterns of relationship between $\mathrm{PH}$ and television stations associated with the purchase and the rights, namely: buy broken up, with the broadcasting rights on television stations; sharing, the broadcasting rights depends on the agreement; and free, broadcasting rights in $\mathrm{PH}$.

One of the important characteristics of soap opera is the concept of cheap and easy to produce, and earns huge profits. So that the characteristics of the soap opera is always located outskirts of Jakarta. Besides, producer is very dominant in the basic concepts of soap opera story, with the premise to fulfill the desire of the television'sowners. The owner's desire usually based on the market trends or specific orders from sponsors.

The script writer does not deal with the television and the audience, but will always follow the wishes of the producer. The writer also does not lay on the basic idea, but only on the technical narrative of the story that must be in the structure of desire forces outside the writer self, such as television stations, producers $\mathrm{PH}$, and the advertisers as well as competitors. When SCTV managed Para Pencari Tuhan (PPT), Islam KTP then RCTI also made Tukang Bubur Naik Haji, When SCTV success with Ganteng-Ganteng Srigala (GGS), RCTI made Tujuh Manusia Harimau, and MNCTV broadcast Manusia Harimau and Vampireand so on.

The strategy to imitate, peek and stalk each other is commonly occurs in television industry. The ability in competing and imitating of the $\mathrm{PH}$ and television can win the market by using various strategies. Many PHs appear, but only a few of them can survive, due to the proximity of relations to the television. For the television owner, it is a form of spatialization and efficiency that can increase revenue. This control eases the MNC to create strategies for fighting and winning the competition with other televisions.

In the soap opera industry, workers (script writers, directors, artists, crew, etc.) were contracted based onthe needs and the period of aired. The payments or awards of the workers depends on the continuity of the soap opera, and based on the professionalism and its success in obtaining and maintaining the rating. High rating often obtained when there is a large element of conflict. Exploitation of conflictand the characterofthings can notbe avoid. Therefore the storylineis often beyond the logic. The healthy logicis often defeated by the elements of interest to obtain a high rating.

${ }^{12}$ Sunardian Wirodono. Matikan TV-Mu: Teror Media Televisi di Indonesia. (Yogyakarta: Resist Book.2005), p. 75. 
The stripping system impacted on the delay sscript and consequently the soap opera made carelessly. To anticipate, the selection of players with some criteria like pretty, handsome and famous are always as a consideration. In addition, some of the main background of conflict and dramatization often come from the society daily life with theme is religion teaching by presenting such images such as mosque, veil, pious family, etc., they were always contrasted with the ugliness and evils ymbols.

\section{Figure 1:}

The Mosqueof Kampung Duku in TBNH Soap Opera

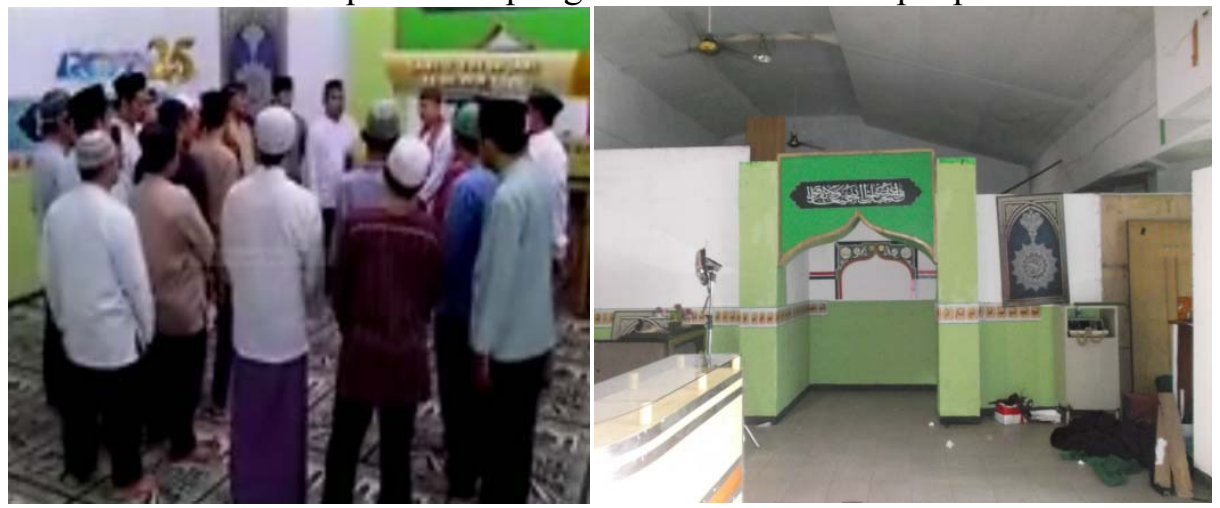

Source: Youtobe and Personal Documents

Figure 1 is a scene in mosque and the property used as a mosque. The mosque is the ultimate symbol representing the places of Muslim worship. Yet this is only used as a mode to get closer to the Muslim community as the target audience. The strategy through the use of religious and cultural basis was supported by strategy without a commercial break between 20 to 40 minutes in the early. But at the end of the show, it was often followed more advertising as stated by the marketing manager RCTI,

"Marketing is very important, because RCTI is a commercial television.

Steps or marketing strategies of RCTI were made aiming to achieve the high ratings and share through evaluating story line of each episode before it is aired. The basic consideration of the strategy 30-40 minutes with no commercial breaks in the early TBNH in order that the viewers do not switch the channel"13.

TBNH soap opera was not different from the other soap operas. It also contained scenes that full of intrigue, envy, jealousy, and resentment. It could be found on Haji Muhidin or Kardun addressed to Haji Sulam's family. This soap opera commodified the Islamic symbols by using words or phrases such as: "Hajj", "Alhamdulillah", “Amirul Mukminin","Juragan Haji RW”, "Haji

${ }^{13}$ ER, Interview,September 23, 2014. 
Kardun Al-Kafirun" and the other symbols of Islam. Those symbols were supported by the use of Betawi culture symbols such as the use of the word: "Empok", "Encing", "Gue", "Lu", and so on. Those symbols in words, sentences and scenes were used only as a strategy to wrap up the story in order to attract audiences and it was constantly repeated through the enlargement of the conflict and multi-plot. The use of Islamic symbols in various scenes were often represented on the headscarf, prayer mats, fashion/cap, and mosquesetting and homes calligraphy. The strategy of using Islamic symbols in the form of words and sentences was dramatized in the sensational scenes, hyperbole, and provocative that was intended to entertain the audience and won advertisers.

The television owners and producers got a lot of revenue from this, so that this soap opera is still produced and aired. The number of advertisers competed for slots on the commercial break of TBNH soap opera sale. In 2013, this soap opera acquired advertisers of 52782 spot with IDR 2.242.185500.000, -. This number was certainly not least, because in a certain period TBNH in one airing consisted of 2 until 3 episode, with a duration of more than four hours.

Table 1:

Total AdvertisementExpenditure of TBNH (1 January to 31 December 2013)

\begin{tabular}{|l|l|l|l|l|}
\hline Channel & Program & $\begin{array}{l}\text { Program } \\
\text { Typology }\end{array}$ & $\begin{array}{l}\text { No. Of } \\
\text { Spots }\end{array}$ & $\begin{array}{l}\text { Cost (in } \\
\text { thousands) }\end{array}$ \\
\hline RCTI & $\begin{array}{l}\text { TUKANG BUBUR } \\
\text { NAIK HAJI THE } \\
\text { SERIES }\end{array}$ & Series: Drama & 52.782 & $\begin{array}{l}2.242 .185 .500,00 \\
\text { Rp }\end{array}$ \\
\hline
\end{tabular}

Source: Nielsen

The Nielsen data showed that advertising spots obtained by TBNH throughout the year 2013 was around 52 782. This means that the average rate card per one spot TBNH was approximately IDR 42.48 million per 30 seconds. From this TBNH only, RCTI can gain a huge advantage. This business orientation of course could ignore the public interest (da'wah or education). Even the soap opera workers and media workers could not avoid the interests of media owners. The target achievement of economical and political interests of media owners was a vortex that formed the media working culture. The television's owner who was also as a political elite, made RCTI notonly as economic institutions and businesses, but also extended it into political institutions. This can be seen from Hary Tanoesoedibjo (HT) who kept trying to take advantage of his media for political purposes, either when he joined to Nasdem, Hanura or his own party, Perindo.

The industrial characteristics and work culture ofsoap opera and RCTI can bring three interests as well, namely the public interest, economic interest, and political interests. As it can be described as follow:

Figure 2: 
The Characteristics of Industry in Soap Opera TBNH and its Slices Interest

Rating basis, the soap operaas an excellent product, femalesegment, cost efficiency, standardized, stripping, carelessly production, imitate each other, etc.

Source: Research results 2015

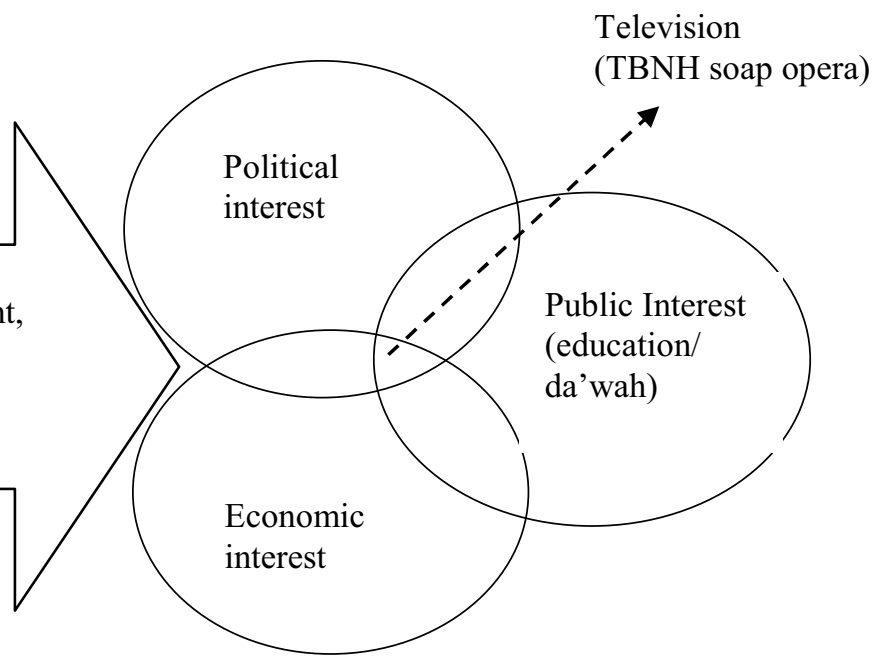

Figure 2 shows the characteristics in the soap opera industry. These characteristics are related to what the dominant interests in the RCTI working culture. The public interest is often neglected because of the television's owner dominance on the economic and political interests which occurs due to the hyper-commersialism and politicization of media owners. The politicization for economic and political interests was not only found on RCTI, but also on all television stations of MNC group, especially before the election held in 2014, a time when the owner of the media becoming the chairman of the Election Campaign Board (Bapilu) Hanura Party. The owner is also a candidate of vice president of the party who was paired with Wiranto (WIN-HT). The utilization could be also found from how HT tried to build opinion in his media to attack the other party or other competitors, namely Siti Hadiati Rukmana (Mbak Tutut) related to MNCTV(TPI) ownership.

\section{The Exploitation of Religious Symbols, Soap operas Workers and Audience}

Hary Tanoesodibjo (HT) as RCTI owner will always establish business strategies to win the competition in the soap opera industry. These activities obviously used the resource basis of culture or religion, the people (workers and audiences) and all media under the MNC control. Through MNC group networks, RCTI could control the workings and production systems of Sinemart.Therefore the producers had always been in the shadow of the RCTI owner.

The use of these resources was a form of exploitation and irregularities practices committed by the capital owners. Currentlythere isa 
spirittobringreligioncloserto themedia ${ }^{14}$. The use ofreligious symbolsdid not make the mediamore religious, becausereligious symbolwere exploited and manipulated. The exploitation has occurred not only on religious or cultural symbols (text), but also on the process of text production:exploitation of workers and audiences of TBNH. The media exploitation by the owner could not be separated from the work culture of authoritarian media. The distinctive feature of the culture of media industry was the division of work that emphasizes more task-oriented rather than working with a predetermined role. The outsourcing of some functions to other companies through $\mathrm{PH}$ or other service providers will always be practiced. This allows the managers to avoid unnecessary layer of bureaucracy. In this case Haryatmoko added:

"The limited contract is the usual practice to avoid payment of social security, health care costs, pensions, and so on. It is done in order not to be bothered by the problem of labor conflict. In this media regime, workers could easily be moved from one task to another. Contract workers changed in accordance with changes in the activity of the company" $"$.

Soap opera industry system involvedmany labors. The workers is not only in the TBNH soap operas and RCTI workers but involves the audience as laborers to produce the rating. The commodification of audience labor related to obtain a high rating. In this case, thewriter called as a process of exploitation of audiences labor. Because exploitation is an integral part of the capitalist labor process. According to Marxists, exploitation is divided into two. Firstly, the absolute exploitation. This is a process of utilization of media workers as much as possible by extending the working day that is held to the same wage. The working system was moving to follow the will of the company owner. Secondly, the relative exploitation. This is the intensification of the labor process through greater control over the use of working time, including the measurement and monitoring systems to get more labor out of the unit prevailing working time ${ }^{16}$.

So the forms of labor utilization that requires more work to produce commodity of soap opera indicated the exploitative production system. Figure 2 below shows that the exploitation of resources not only to accumulate capital, but also to enlarge the political purposes. The owner not only conveyed the political message through the usual media through news or advertising, but also

${ }^{14}$ S.H. Hosseini. "Religion and Media, Religious Media, or Media Religion: Theoritical Studies". Journal of Media and Religion. 2008, 7, p. 56.

${ }^{15}$ Haryatmoko.Etika Komunikasi: Manipulasi Media, kekerasan dan Pornografi. (Yogyakarta: Kanisius.2007), p. 58.

${ }^{16}$ Vincent Mosco. Op.Cit. 131. 
through soap operas, reality shows, and even the operational vehicles of the company.

Figure 2:

The Exploitation of Media Resources in MNC Group

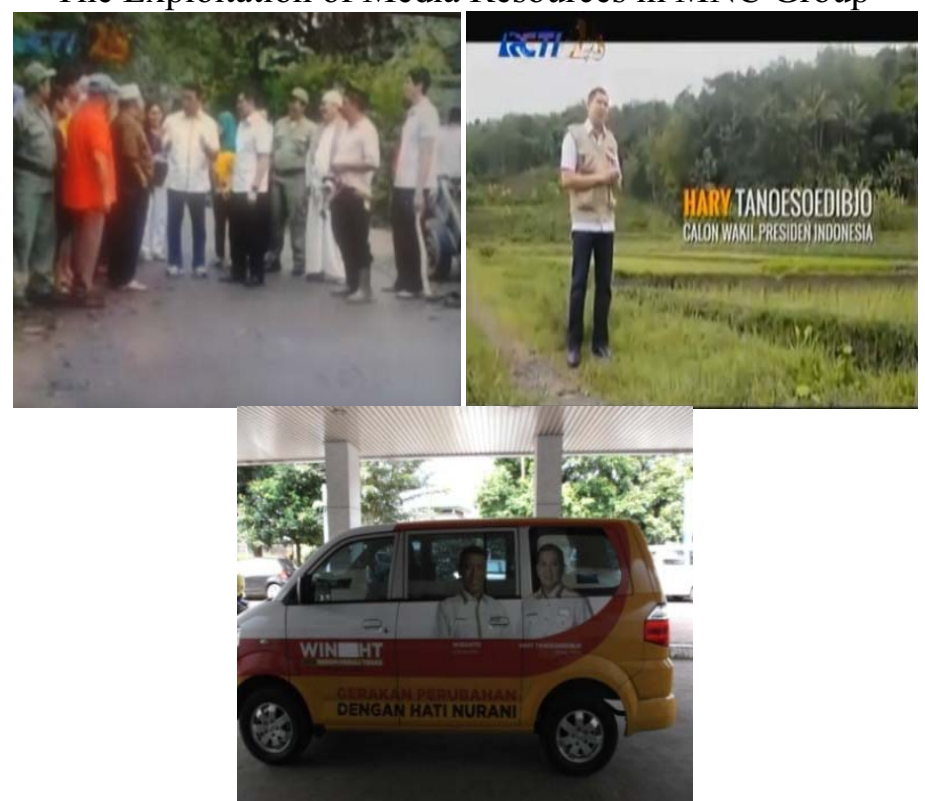

Source: Personal Documents

Figure 2 above shows that there are many ways to utilize the media and media workers under the control of the MNC corporation. The owner would easily use the available resources to be exploited for political purposes such as making a program Mewujudkan Mimpi Indonesia, Kuis Kebangsaanor play in the TBNH soap opera. HT used his televisions, newspapers and other media companies even the operational vehicles for political interests. The use of workers for the owners benefit also indicates how hard the MNC workers to not support the owner. Therefore, it can be asserted that media workers have two jobs:to make money as commercial work and to expand the influence as political work ${ }^{17}$.

Through religious soap opera, RCTI owner simultaneously has exploited the religious symbols of Islam, media workers, and also the audiences to accumulate the capital. Self-identification plays an important role in the consumption of Islamic culture. It is connected directly between Muslim identity and consumption process, and it indicates the extent to which a product

${ }^{17}$ Kumru Berfin EmreCetin. “The 'Politization' of Turkish Television Drama”.International Journal of Communication 8. 2014, p: 2474. 
provides the "proximity symbolic market"18. The Islamic community as a major segment of this programis expected to consume thissoap opera continuously.

Therefore, the text (symbol) commodification could not be separated from the commodification of labours and audiences.The authoritarian television industry process was a form of workers exploitation. Therefore, the author can assert that the exploitation occured at three levels: the text or symbols, workers, and audiences.

Firstly, the exploitation of Islamic and Betawi symbols. Religious and cultural symbols, and a set of values inherent were commodified as a marketing strategy to get the high ratings. Those symbols as package/commoditywere aired and traded to get the surplus value (profit) through sponsorship and advertising. Secondly, the exploitation of soap operas workers and RCTI workers. The labor exploitation occuredfor those who generate profits for the company, both those who work for Sinemart and RCTI. These workers are required to work based on standardized operation (SOP). They must not violate the existing rules. The labours must comply and adhere all the rules imposed based on employment contract that binds them.This control indirectly "force" them, if not,they would be sanctioned or even discharged. The workerswere rewarded based ontheir respective professions. The exploitation happened when the owner treated the workers as machines to earn money by adding excessive working time ${ }^{19}$.

Thirdly, the audience exploitation. Audienceis an important aspectof the soap opera industry, becausethe audienceis a commoditythat could be commodified and exploited ${ }^{20}$. Nielsen sold the audiences to RCTI through television ratings data, andthen RCTI sold the audiences to the advertisers. The audience watching activity was an effort to employ the audience as labour that could accumulate profits for the television owner. Television needs the audience as laborerfor the sustainability of the industry by making the audience as aloyal customer. The exploitation happens when audience has loyality. The audience actually does not get any thing except apparent pleasure and empty soul because of alienation.

The three aspects of exploitation are interconnected, the text was produced by workers, and the text was consumed by audiences. The workers were paid based on professionalism in the contract, and also based on the rating obtained. While the audience only got pleasure from watching. The logic of this

\footnotetext{
${ }^{18}$ Pattana Kitiarsa.Religious Commodifications in Asia: Marketing Gods. (London: Routledge. 2008), p. 8.

${ }^{19}$ VincentMosco, Op.Cit. 41.

${ }^{20}$ BriceNixon, Op.Cit. 715. Nixonused this term"audience labor"refers to theaudience activityof socialmediausers.
} 
exploitation was in conformity with efforts to commercialize and commodify which can generate more profits for the capital owners.

Long time ago, Marx made it clear where in those who have power (elite) especially media owner can exploit the working class both media workers (soap opera worker) and the audience. This position can create the alienation or psychological condition to feel that they have little control over their future. For Marx alienation would be the most damaging under capitalism ${ }^{21}$. When people have lost control over their own production and have to sell their time to employer. They become alienated.

Table 2:

Strategy and mode of exploitation in TBNH Soap Opera

\begin{tabular}{|c|c|c|}
\hline Level & Producer/Media Owner Strategy & Identification \\
\hline Text & $\begin{array}{l}\text { 1) Using Islamic symbols } \\
\text { 2) Using Betawi symbols } \\
\text { 3) Making sensational, } \\
\text { provocative and hyperbole } \\
\text { words and sentences in order } \\
\text { to attract and entertain } \\
\text { audiences. } \\
\text { 4) Shooting with close-up } \\
\text { objects that wanted to attract } \\
\text { audiences. }\end{array}$ & 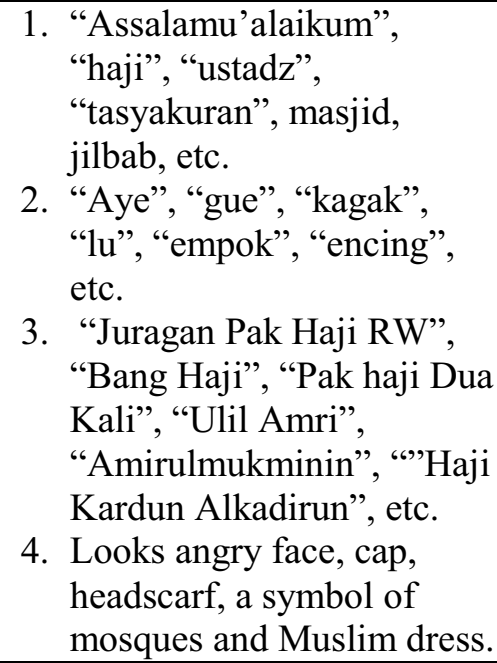 \\
\hline Labor & $\begin{array}{l}\text { 1) Contractsper episode(the } \\
\text { contractcan be terminatedat } \\
\text { any time because of the } \\
\text { rating) } \\
\text { 2) Stripping (to maintain the } \\
\text { audience loyalty) } \\
\text { 3) Pay attention to the plot or } \\
\text { story line } \\
\text { 4) Purchasingsoap opera } \\
\text { (efficiency of production }\end{array}$ & $\begin{array}{l}\text { 1. Per episode of salary } \\
\text { payment } \\
\text { 2. Shooting was done until } \\
\text { evening and the workers } \\
\text { must be at the location } \\
\text { everyday } \\
\text { 3. Create a multi-plot story } \\
\text { and develop conflict and } \\
\text { involve new players } \\
\text { 4. Use Sinemart as production }\end{array}$ \\
\hline
\end{tabular}

${ }^{21}$ Richard West \& Lynn H. Turner.Pengantar Teori Komunikasi; Analisis dan Aplikasi, Edisi 3, Translated by Maria Natalia Damayanti Maer, (Salemba Humanika, Jakarta.2008), h. 64. 


\begin{tabular}{|c|c|c|}
\hline & $\begin{array}{l}\text { costs: employees, offices, and } \\
\text { others) }\end{array}$ & hause for cost efficiency \\
\hline Audience & $\begin{array}{l}\text { 1) Soap opera aired without } \\
\text { commercial } \\
\text { breakover30minutesatthe } \\
\text { beginning. } \\
\text { 2) Promotion to remind at RCTI } \\
\text { and other media. } \\
\text { 3) Political stategies of HT } \\
\text { andhis Party. } \\
\text { 4) Imitate and peek each other } \\
\text { among the television stations }\end{array}$ & $\begin{array}{l}\text { 1. To attract viewers keep on } \\
\text { watching continually. } \\
\text { 2. Appear in a variety of } \\
\text { media MNC group such } \\
\text { commercial break or other } \\
\text { spaces } \\
\text { 3. Emerging political } \\
\text { advertising HT, Hanura and } \\
\text { Perindo frequently. } \\
\text { 4. Scramble and piracy artist } \\
\text { or audiences of other } \\
\text { televisions by making the } \\
\text { same soap opera genre. }\end{array}$ \\
\hline $\begin{array}{l}\text { Capital } \\
\text { owner/ } \\
\text { Ideology }\end{array}$ & $\begin{array}{l}\text { 1) Exploit the text, symbols and } \\
\text { media } \\
\text { 2) Exploit the workers } \\
\text { 3) Exploitation and sell the } \\
\text { audiences to advertisers } \\
\text { 4) Perpetuate the ideology of } \\
\text { capitalism }\end{array}$ & $\begin{array}{l}\text { 1. The excessive use of } \\
\text { religious and Betawi } \\
\text { symbols } \\
\text { 2. The commodification of } \\
\text { expertise and sell the work } \\
\text { of subordinate and seasonal } \\
\text { workers bylow-paid } \\
\text { 3. Audiences are used as a } \\
\text { commodity and labor by } \\
\text { using various marketing } \\
\text { and packaging strategies } \\
\text { 4. Spreading myths of } \\
\text { goodness and da'wah } \\
\text { through Islamic symbols. }\end{array}$ \\
\hline
\end{tabular}

Source: Research Findings 2015.

Table 2 presents the construction of the various strategies and modes performed by the power of owner associated with the capital accumulation. In addition, the aspects of the commodity and exploitation based on the strategy of the power owner. Therefore, the exploitation of these resources and aspects were utilized for the benefit of both economic and political interests of media owner. Hyper-commercialism in the use of religious symbols is quite successful in achieving the goal of capital accumulation. The success can be seen from the survival of the TBNH soap opera to reach thousands of episodes and always stable in the top rank of the rating. Meanwhile, the utilization for political purposes bythe media owners has not been so visible. It is based on the number of Hanura Party votes, in the elections 2014. In fact, the Hanura vote decreased 
in number compared topreviouselections. This could be as a result of too much information messages delivered.

\section{E. Conclusions}

RCTI owners had abused the power of the communication resources. This great power gave rise to several forms of exploitation the level ofthe texts or symbols, workers and audiences. Exploitation of religious symbols of Islam and Betawi culture occurred excessively in terms of sensational, provocative and hyperbole words/sentences. In addition there are many scenes were constructed with various modes in order to entertain audiences and finally to attract the advertisers. Exploitation of mosque, veil, calligraphy, and other Islamic symbols, as well as verbal symbols and artifacts of Betawi culture were clearly as the main product and packaging to be used as a commodity to be commercialized.

The soap opera workers (both artists and crew) were exploited through the various strategies and modes. They were employed to produce the soap opera with no definite time limit continually. While audiences exploitation occured commonly in women of Muslim society. They wereused as a commodity traded among rating agencies, television stations and advertisers. The audiences had also been used as laborers, because the audiences were expected and required to watch soap operas continually. By producing meaning that aired, audiences indirectly had been producing the ratings, brought in advertisers, and made money for the media owner, so that the industry could run continuously.

Therefore, the perspective of political economy of communication was needed to understand and examine the social relations in the aspect of communication, especially in the television industry which was more concentrated. The television industry was getting creative, so it was required more critical research to create literate society toward media and industries cared about the public. The capitalist media will always use a variety of efforts to accumulate the capital. Therefore, the Muslim audiences should be aware that the commercial media broadcasting system will always utilize the Islamic symbols and the audiences for their own purposes. 


\section{REFERENCES}

Cetin, Kumru Berfin Emre, 2014, “The 'Politization' of Turkish Television Drama”. International Journal of Communication 8 (2014).

Gokariksel, Banu \& Ellen McLearny, 2010, "Muslim Woman, Consumer Capitalism and the Islamic Culture Industry", Journal of Middle East Woman's Studies, Volume 6, Number 3, Indiana University Press.

Haryatmoko, 2007, Etika Komunikasi: Manipulasi Media, kekerasan dan Pornografi. Yogyakarta: Kanisius.

Hosseini, S.H., 2008,. "Religion and Media, Religious Media, or Media Religion: Theoritical Studies". Journal of Media and Religion. 2008, 7: 56-69.

Kitiarsa, Pattana ed., 2008, Religious Commodifications in Asia: Marketing Gods. London: Routledge.

McQuail, Denis. 2011. Teori Komunikasi Massa, Buku 1- Edisi 6, Translated by Putri Iva Izzati. Jakarta: Salemba Humanika.

Mosco, Vincent, 2009, The Political Economy of Communication, Second Edition. New York: Sage Publication.

Morisan, 2008, Manajemen Media Penyiaran.Jakarta: Kencana,).

Musman, Asti \& Sugeng WA, 2011, Marketing Media Penyiaran: Bukan Sekedar Jual Kecap. Yogyakarta:Cahaya Atma Putaka.

Nixon, Brice, 2014, "Toward a Political Economy of 'Audience Labour' in Digital Era". Triple-C: Journal for Global Sustainable Information Society: 12 (2).

Sudibyo, Agus, 2004, Ekonomi Politik Media Penyiaran. Yogyakarta: LKiS.

Syahputra, Iswandi,2011,Rahasia Simulasi Mistik Televisi. Yogyakarta: Pustaka Pelajar.

West, Richard \& Lynn H. Turner, 2008, Pengantar Teori Komunikasi; Analisis dan Aplikasi, Edisi 3, Buku 2, Translated byMaria Natalia Damayanti Maer, Salemba Humanika, Jakarta.

Wirodono, Sunardian, 2005, Matikan TV-Mu: Teror Media Televisi di Indonesia. Yogyakarta: Resist Book. 


\title{
THE EFFECT OF SPIN-OFF POLICY ON FINANCING GROWTH IN INDONESIAN ISLAMIC BANKING INDUSTRY
}

\author{
M. Nur Rianto Al Arif \\ UIN Syarif Hidayatullah Jakarta \\ (nur.rianto@uinjkt.ac.id)
}

\begin{abstract}
The purpose of this paper is to analyze the relationship between spin-off policy on the financing growth of Islamic banking industry in Indonesia. This research used panel regression with fixed effect. The variable used in this paper is dummy variabel of spin-off, and also included the internal factor of industry such as third party fund, and efficiency ratio (measured by BOPO). Besides the internal factor, this research also included the external factor such as inflation rate, economic growth rate, and interest rate from conventional banking. The result shows that only third part funds and interest rate had an impact on the financing growth in spin-off banks. The spin-off policy doesn't have an impact on the financing growth in spin-off banks
\end{abstract}

Tujuan dari penulisan artikel ini ialah untuk menganalisis keterkaitan antara kebijakan pemisahan terhadap pertumbuhan pembiayaan pada industri perbankan syariah di Indonesia. Penelitian ini menggunakan teknik regresi panel dengan model efek tetap. Variabel yang dipergunakan dalam artikel ini ialah variabel dummy pemisahan, serta memasukkan pula faktor internal seperti dana pihak ketiga dan rasio efisiensi yang diukur dari BOPO. Selain itu dimasukkan pula faktor eksternal seperti tingkat inflasi, tingkat pertumbuhan ekonomi, dan tingkat suku bunga dari bank konvensional. Hasil yang ada menunjukkan bahwa hanya dana pihak ketiga dan tingkat bunga yang memiliki pengaruh terhadap pertumbuhan pembiayaan di bank syariah yang pisah. Kebijakan pemisahan tidak memiliki pengaruh terhadap pertumbuhan pembiayaan di bank syariah yang pisah.

Keywords: spin-off, financing, panel regression 


\section{A. Introduction}

July 16, 2008, has passed Law No. 21 of 2008 concerning Islamic Banking. With the passing of this law provides the legal basis and the national Islamic banking industry is expected to encourage the development of Islamic banking industry for the better. One of the crucial issues in this legislation that can accelerate the development of Islamic banking in Indonesia is related to the separation (spin-off) Islamic business units both voluntary and mandatory if the asset Islamic business unit has reached $50 \%$ of the parent bank's assets or 15 years after the Act No. 21 of 2008 applied.

Islamic banking has grown rapidly in Indonesia. This is shown by the development of third-party funds, financing and distribution of assets in the Islamic banking industry from the years before the regulations regarding the spin-off and after the rule of the spin-off. Seen that from year to year, that an increase in either of assets, third-party funds, and the distribution of financing in Islamic banks.

Table 1. The Growth of Third Party Fund, Financing and Asset (Billion rupiah)

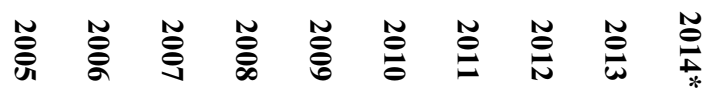

\begin{tabular}{|c|c|c|c|c|c|c|c|c|c|c|}
\hline Fundraising & $\begin{array}{l}\vec{u} \\
\dot{\omega} \\
\stackrel{\infty}{N}\end{array}$ & $\begin{array}{l}\text { Oे } \\
\dot{\vec{N}}\end{array}$ & $\begin{array}{l}\infty \\
\stackrel{N}{O} \\
\stackrel{O}{=}\end{array}$ & $\begin{array}{l}\omega \\
\stackrel{\omega}{\omega} \\
\dot{\omega} \\
\tilde{N}\end{array}$ & 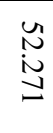 & $\begin{array}{l}\vec{\alpha} \\
\dot{d}\end{array}$ & $\begin{array}{l}\bar{n} \\
\dot{t}\end{array}$ & & & 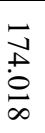 \\
\hline Financing & $\begin{array}{l}\underset{\cup}{\tilde{\omega}} \\
\stackrel{\omega}{\omega}\end{array}$ & $\begin{array}{l}\stackrel{N}{O} \\
\stackrel{+}{E}\end{array}$ & 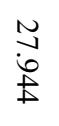 & $\begin{array}{l}\omega \\
\infty \\
\dot{\phi} \\
\stackrel{+}{\circ}\end{array}$ & $\begin{array}{l}t \\
\text { aे } \\
\infty \\
\infty \\
\infty\end{array}$ & $\underset{\infty}{\infty}$ & 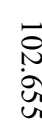 & & & 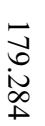 \\
\hline Asset & $\begin{array}{l}\tilde{O} \\
\infty \\
\dot{0} \\
0\end{array}$ & $\underset{\stackrel{N}{N}}{\stackrel{N}{N}}$ & $\begin{array}{l}\mathscr{\omega}_{u} \\
\stackrel{u}{u}\end{array}$ & $\begin{array}{l}\vec{t} \\
\dot{\dot{u}} \\
\text { ü }\end{array}$ & $\begin{array}{l}\text { के } \\
\dot{8}\end{array}$ & $\begin{array}{l}\stackrel{0}{u} \\
\underset{\sigma}{0}\end{array}$ & & & & 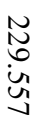 \\
\hline
\end{tabular}

Source: Islamic banking statistics, Bank of Indonesia

Total funding from year to year showed an increasing trend. However, from the composition of financing provided shows that the largest financing agreement was extended on murabaha contract is equal to $60 \%$ of the total financing. Though supposedly financing contract in Islamic banks must be located in profit-sharing contracts (such as mudaraba and Musharaka). Ones of the things that differentiates between conventional banking Islamic banking in addition to associated with interest is whether Islamic banking is really able to 
move the real sector which in this case can be seen from its influence on the level of investment.

\section{Table 2. Financing Composition in Islamic Banking (Billion rupiah)}

\begin{tabular}{|c|c|c|c|c|c|c|c|}
\hline Contract & 气్̊̆ & 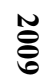 & $\stackrel{\tilde{O}}{\theta}$ & $\stackrel{N}{\Xi}$ & $\stackrel{\widetilde{N}}{\stackrel{N}{N}}$ & $\stackrel{\widetilde{S}}{\omega}$ & $\stackrel{N}{\Xi}$ \\
\hline Mudharabah & 宂 & i্ & $\begin{array}{l}\infty \\
\dot{\omega}\end{array}$ & $\stackrel{\text { D }}{\underset{\text { N }}{\text { N }}}$ & $\begin{array}{l}\bar{N} \\
\stackrel{\tilde{N}}{\omega}\end{array}$ & $\begin{array}{l}\bar{\omega} \\
\dot{\alpha} \\
\dot{\phi}\end{array}$ & $\begin{array}{l}w \\
\dot{\omega} \\
\dot{0}\end{array}$ \\
\hline Musyarakah & $\stackrel{\vec{E}}{\Xi}$ & $\begin{array}{l}\overrightarrow{0} \\
\stackrel{+}{N}\end{array}$ & $\begin{array}{l}\overrightarrow{+} \\
\dot{\vec{D}} \\
\dot{+}\end{array}$ & $\begin{array}{l}\vec{\infty} \\
\dot{8} \\
8\end{array}$ & 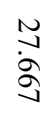 & 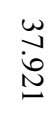 & $\begin{array}{l}\stackrel{t}{i} \\
\dot{\infty} \\
\mathscr{d}\end{array}$ \\
\hline Murabahah & \begin{tabular}{l}
$N$ \\
$N$ \\
$\stackrel{N}{*}$ \\
\multirow{2}{*}{}
\end{tabular} & $\begin{array}{l}\stackrel{N}{\sim} \\
\stackrel{N}{N}\end{array}$ & $\begin{array}{l}\text { w } \\
\dot{\ddot{\omega}} \\
\infty\end{array}$ & 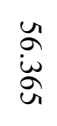 & $\begin{array}{l}\infty \\
\infty \\
\dot{\varnothing} \\
\varnothing\end{array}$ & $\begin{array}{l}\overrightarrow{.} \\
\overrightarrow{+} \\
\stackrel{+}{+} \\
+\end{array}$ & $\begin{array}{l}\bar{N} \\
\text { N } \\
\infty\end{array}$ \\
\hline Istishna & 亗 & 志 & $\stackrel{\omega}{ \pm}$ & Nू & $\vec{J}$ & $\underset{\infty}{\mathbb{\infty}}$ & $\underset{\infty}{u}$ \\
\hline Ijarah & 宓 & $\overrightarrow{\dot{\omega}}$ & $\begin{array}{l}\underset{\omega}{\sim} \\
\stackrel{ \pm}{ \pm}\end{array}$ & $\begin{array}{l}w \\
\dot{w} \\
\underset{\sigma}{\infty}\end{array}$ & $\begin{array}{l}\vec{\omega} \\
\dot{\omega} \\
\dot{\omega}\end{array}$ & $\begin{array}{l}\overrightarrow{\tilde{N}} \\
\dot{\mathbb{E}}\end{array}$ & $\underset{i}{\vec{\omega}}$ \\
\hline Qardh & 离 & 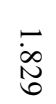 & $\stackrel{\vec{\omega}}{\omega}$ & $\begin{array}{l}\bar{N} \\
\stackrel{0}{u} \\
\text { U. }\end{array}$ & $\begin{array}{l}\bar{N} \\
\dot{0}\end{array}$ & $\begin{array}{l}\stackrel{0}{+} \\
\stackrel{+}{+}\end{array}$ & $\stackrel{\infty}{0}$ \\
\hline
\end{tabular}

\section{Total}

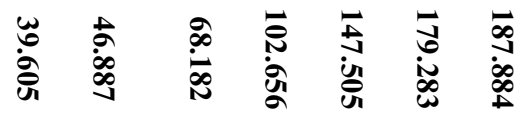

Source: Islamic banking statistics, Bank of Indonesia

According Tübke ${ }^{1}$ there are several factors that affect the separation process (spin-off). First, the factors associated with the business activity, the

1 Alexander Tubke. Success Factors of Corporate Spin-Offs. (New York: Springer, 2004), p. 30 
first factor is related to the size of the company and the business sector differences between the parent company to its subsidiaries. If the first factor is associated with the Islamic business unit can be positioned as a conventional bank subsidiaries and parent company. Second, the factors associated with the organization and management of the company. Third, factors associated with relationships and support. There are three patterns of relationships that may be created between the parent company with subsidiaries which perform the separation, namely the relationship market (market-Relatedness), the relationship of the product (product Relatedness), and the relationship of technology (technology-Relatedness). Fourth, transfer factor or transfer such transfer of experience from the parent company to its subsidiaries. Fifth, factors associated with motivation. Sixth, the factors associated with the business environment in the form of the characteristics of the regional business environment and legal framework

Nasuha conducted a study related to differences in the performance of Islamic business unit who decided to split (BNI Sharia, BRI Sharia, BJB Sharia, BSB, and Bank Victoria Sharia) one year before and one year after the spin-off by using the Wilcoxon analysis Match Pairs test which is a refinement of the test mark (sign test). The results obtained are of the nine variables, assets, financing, deposits, net profit, CAR, NPF, FDR, ROA, and ROE were tested with Wilcoxon Signed Ranks Test method shows that the performance difference between before and after the spin-off occurred on 3 variables, i.e. assets, financing, and Third Party Fund (TPF). It can be seen from the significant value that is less than $\alpha$. That is, there is the effect of the spin-off activity before and after. While on the other variables, CAR, FDR, ROA, and ROE showed no difference in performance between 1 year before and 1 year after the spin-off, with a significance value greater than $\alpha$. This might be due to the spin-off is still practiced in the new Islamic banking industry, so the testing period was short.

This research aims to analyze the impact of spin-off policy on the financing growth in Islamic banking industry. This research will show whether the Islamic commercial bank resulted from spin-off can increase the financing after the spin-off decision. The finding of this research will contribute the spinoff practice on Islamic banking industry in Indonesia.

Differentiation this research over previous researches is as follows. First, this research uses the panel data from four Islamic commercial bank resulted from spin-off. Second, the study discusses about the spin-off of Islamic banking is still very limited, so this research will make a significant contribution to the development of the theory of spin-offs of Islamic banking. Third, this research analyzes does the spin-off policy had an impact on financing growth of Islamic banking industry. 
To achieve the goal of this research analyzing the influence of spin-off policy on the financing growth of Indonesian Islamic banking, regression with panel data analysis is used.The data used are quarterly data from 2005 to 2014 , by including four Islamic banks spinoff (such as BNI Syariah, BRI Syariah, Bukopin Syariah, and BJB Syariah). Statistical data comes from Bank Indonesia Islamic banking and Islamic commercial bank's financial statements results of the spin-off which is the object of research.

The mathematical equation proposed in this research is:

$Y_{\text {it }}=\alpha+\beta_{1} D_{\text {it }}+\beta_{2}$ Fund $_{\text {it }}+\beta_{3}$ Eff $_{\text {it }}+\beta_{4}$ Inflation $_{t}+\beta_{5}$ Interest $_{t}$ $+\beta_{6}$ Growth $_{\mathrm{t}}+\varepsilon_{\mathrm{it}}$

where:

$Y_{i t}=$ financing;

$D_{i t}=$ Dummy variable for spin-off

Which is: 0 before spin-off, 1 after spin-off

Fund $_{\text {it }}=$ third party fund

Eff $_{\text {it }}=$ operational efficiency ratio

Inflation $_{\mathrm{t}}=$ inflation rate

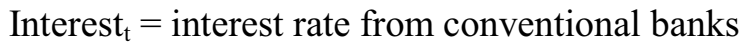

Growth $_{\mathrm{t}}=$ economic growth of Indonesia

To estimate the parameter of the model using panel data regression, there are several techniques that can be used, such as: First, ordinary least square. Second, fixed effect model. Third, random effect model. On these research is using panel regression with fixed effect model, because we assume that the intercept is not constant.

\section{B. Literature Review}

Until now there has not been a lot of theories or research found associated with the spin-off in Islamic banks. This is due to the spin-off of the new Islamic banks only first practiced in Indonesia. Therefore, theories or models of the spin-off will be done with the model of spin-offs are applied to industry in general.

According Elfring and Foss ${ }^{2}$ there are two types of spin-off, namely: first, in terms of its parent company, in which the parent company for some reason is not able or not able to exploit the opportunities that come by. The

${ }^{2}$ T. Elfring, T. \& N.J. Foss. Corporate Renewal Through Internal Venturing and Spin-offs: Perspectives from Organizational Economics. (Working Paper 97-7. Department of Industrial Economics and Strategy Copenhagen Business School, 1997), p. $8-10$ 
second type is related to organizational units as an individual, in this second type is the type most widely performed, in which the subsidiary is not the same as its parent company. This second type contained in the spin-off of the Islamic banking units in conventional banks in Indonesia.

Klepper and Thompson ${ }^{3}$ said that there are three themes of spin-off. First, many of the spinoffs were based on technical ideas that originated within their parent firm but the parent declined to support aggressively or at all. Second, a number of the spinoffs were based on disagreements over the strategic direction of the parent firm and/or fundamental management practices related to the organization of the parents and its method of rewarding high-level employees. Third, founders of the spinoffs were often top managers, including founders and CEOs, and/or top scientist and engineers.

Chemmanur and $\mathrm{Yan}^{4}$ developed a new rationale for corporate spinoffs, and for the performance and value improvements following them. The firm has two divisions, and current management has differing abilities for managing these two divisions. Spin-offs can enhance firm management. In addition, on their analysis demonstrates that in addition to positive abnormal stock-price return on the announcement day, spin-offs also lead to positive long-term abnormal stock returns (on average) for parent spin-offs combination reporting subsequent takeover activity.

Bchini $^{5}$ assess the opportunity of the use of spin-off to ensure both growth and entrepreneurial success in the Tunisian context. This paper identified three forms of spin-off in Tunisia such as the project spin-off, the outsourcing spin-off, and extrapreneurship. Each type leads to growth and entrepreneurial success, but the most successful form is extrapreneurship.

$\mathrm{Ch} \mathrm{u}^{6}$ done the study that bridges a gap in current literature by providing empirical evidence of factors affecting the performance of non-academic spinoffs originating from the Acer Group in Taiwan. The analytical result obtained by this study highlight two issues. First, spin-off performance is likely to be enhanced if its operations are linked to those of the parent. Second, a spin-off performs better during its initial stages if it is an internal venture spun out from

${ }^{3}$ S. Klepper, S. P. Thompson. Disaggrements and Intra-Industry Spinoffs. (International Journal of Industrial Organization, Elsevier, vol. 28(5), September 2010), p. 526-538.

${ }^{4}$ T.J. Chemmanur, \& A.Yan. A Theory of Corporate Spin-offs. (Journal of Financial Economics, Elsevier, Vol. 72, Issue 2, May 2004), p. 259-290.

${ }^{5}$ Bchini, B. Spin-off: Factor of Growth and Entrepreneurial Success: The Example of Tunisia. (International Journal of Business and Social Science, Vol. 3, No. 12, June 2012), p. 65-75.

${ }^{6}$ Chu, P.Y., et. al. Spin-off Strategies and Performance: A case study of Taiwan's Acer Group. (Asian Business and Management, 2010, Vol. 9, 1), p. 101-125 
the parent company with its technology researched and developed within the parent.

Nasuha $^{7}$ done the research about the performance difference on Islamic banking unit that decided to spin-off, such as BNI Shariah, BRI Shariah, BJB Shariah, BSB and Victoria Shariah. The research is done by Wilcoxon Match Pairs test that saw the performance between pre and post spin-off decision on Islamic banking units. The result shown that only asset, financing and third party funds that shown a difference between before and after spin-off policies on that five banks. Otherwise for other variables such as CAR, FDR, ROA and ROE shown that there were no difference on CAR, FDR, ROA and ROE in Islamic banks.

\section{Result and Dicussion}

The estimation result from panel regression with fixed effect shows that the variables affect the financing on Islamic banks result from spin-off are dummy third party fund and interest rate. Intercept give a positive and significant result, these things shows that if all variables on this model are assumed zero, the Islamic banks will still distributed the financing as an intercept coefficient value. Significant results in third party funds variable indicates that the higher third-party funds that can be done by Islamic banks, it will increase the amount of the finance portfolio of Islamic banks.

Interest rates variable have a positive influence on the growth of the finance portfolio in Islamic banks. This happens because if the interest rate on conventional bank financing is higher than the margin of financing of Islamic banks, there will be a transfer of customer financing from conventional banks to Islamic banks.

\section{Table 3. The Estimation Result}

Dependent Variable: PEMBIAYAAN

Method: Panel EGLS (Cross-section weights)

Periods included: 39

Cross-sections included: 4

Total panel (balanced) observations: 156

Linear estimation after one-step weighting matrix

\begin{tabular}{ccccc}
\hline \hline Variable & Coefficient & Std. Error & t-Statistic & Prob. \\
\hline \hline C & 1466447. & 534324.8 & 2.744486 & 0.0068 \\
D_SPINOFF & 44730.50 & 98110.44 & 0.455920 & 0.6491
\end{tabular}

${ }^{7}$ Amalia Nasuha. The Impact of Spin-off Policy on Islamic Bank Performance. (Al-Iqtishad Journal, Vol. IV, No. 2, July 2012), p. 241-258. 


\begin{tabular}{cllll} 
FUND & 1.154882 & 0.013208 & 87.43722 & 0.0000 \\
EFF & 724.3612 & 1640.595 & 0.441523 & 0.6595 \\
INFL & 668968.4 & 947560.8 & 0.705990 & 0.4813 \\
INT & 197468.5 & 95837.19 & 2.060458 & 0.0411 \\
GROWTH & 58416.65 & 52721.55 & 1.108022 & 0.2697 \\
\hline \hline
\end{tabular}

Effects Specification

Cross-section fixed (dummy variables)

Weighted Statistics

\begin{tabular}{lllr}
\hline \hline R-squared & 0.993636 & Mean dependent var & 7030817. \\
Adjusted R-squared & 0.993244 & S.D. dependent var & 10682925 \\
S.E. of regression & 858333.4 & Sum squared resid & $1.08 \mathrm{E}+14$ \\
F-statistic & 2532.888 & Durbin-Watson stat & 1.682320 \\
Prob(F-statistic) & 0.000000 & & \\
\hline
\end{tabular}

Unweighted Statistics

\begin{tabular}{lcll}
\hline \hline R-squared & 0.960695 & Mean dependent var & 3753012. \\
Sum squared resid & $1.39 \mathrm{E}+14$ & Durbin-Watson stat & 2.876573 \\
\hline \hline
\end{tabular}

The value of determination coefficient shows by the value of $\mathrm{R}^{2} 0.9936$ and the value of adjusted $\mathrm{R}^{2} 0.9932$. This result shows that fixed effect model can explain the model in about $99.32 \%$ and $0.68 \%$ is explained by other variables outside the model. The value of $F$ statistics show significant results, so that it can be said that simultaneously all variables affect the dependent variable of financing in Islamic banks. Further test is done to see whether the use of fixed effects model has the added value compared to the pooled OLS. In Table 5 , the value of the $F$ statistic indicates a value of 25.225 with a $p$ value of 0.00 . Thus it can be said that the fixed effects models provide significant added value compared with the pooled OLS models.

Table 4. Likelihood Ratio Test

Redundant Fixed Effects Tests

Equation: Untitled

Test cross-section fixed effects

\begin{tabular}{llll}
\hline \hline Effects Test & Statistic & d.f. & Prob. \\
\hline \hline
\end{tabular}


Cross-section fixed effects test equation:

Dependent Variable: PEMBIAYAAN

Method: Panel EGLS (Cross-section weights)

Periods included: 39

Cross-sections included: 4

Total panel (balanced) observations: 156

Use pre-specified GLS weights

\begin{tabular}{crrrr}
\hline \hline Variable & Coefficient & Std. Error & t-Statistic & Prob. \\
\hline \hline C & 736333.2 & 602614.8 & 1.221897 & 0.2237 \\
D_SPINOFF & -183956.5 & 115191.7 & -1.596960 & 0.1124 \\
FUND & 1.205434 & 0.012755 & 94.50576 & 0.0000 \\
EFF & 1175.511 & 1843.276 & 0.637729 & 0.5246 \\
INF & 712682.9 & 1155203. & 0.616933 & 0.5382 \\
INT & -18732.16 & 110302.0 & -0.169826 & 0.8654 \\
GROWTH & -100279.0 & 63727.92 & -1.573550 & 0.1177 \\
\hline \hline & Weighted Statistics & & \\
\hline \hline R-squared & 0.990338 & Mean dependent var & 7030817. \\
Adjusted R-squared & 0.989948 & S.D. dependent var & 10682925 \\
S.E. of regression & 1046939. & Sum squared resid & $1.63 \mathrm{E}+14$ \\
F-statistic & 2545.259 & Durbin-Watson stat & 1.171774 \\
Prob(F-statistic) & 0.000000 & & & \\
\hline \hline
\end{tabular}

Unweighted Statistics

\begin{tabular}{lcll}
\hline \hline R-squared & 0.955376 & Mean dependent var & 3753012. \\
Sum squared resid & $1.58 \mathrm{E}+14$ & Durbin-Watson stat & 2.623773 \\
\hline
\end{tabular}

The results obtained in this study indicate that factors influencing the amount of financing are third-party funds and the interest rate. This result is similar with Asy'ari $^{8}$, his research shown that the factors that affect on financing growth are third party fund and interest rate. Ambarwati ${ }^{9}$ also found

${ }^{8}$ Mohammad Hasyim Asy'ari. The Factors That Influence Islamic Bank's Financing. (Unpublished Thesis). (Depok: Universitas Indonesia, 2009)

9 Septiana Ambarwati. The Factors That Influence the Murabahah and Mudharabah Financing on Indonesian Islamic Commercial Banking. (Unpublished thesis). (Depok: Universitas Indonesia, 2011), 
that the credit interest rate on conventional banking had a significant influence on the financing growth on Islamic banking. Besides the interest rate, the other variable that also had an affect are non performing finance and SWBI bonuses.

Adebola et.al ${ }^{10}$ investigates the impact of conventional bank interest rate on the volume of financing of Islamic banks in Malaysia. His study shows that interest rate significantly affects Islamic banks financing in Malaysia. This is taken to mean that Islamic banks financing is complementary rather than substitute to conventional banks financing. Hence, it is recommended that Islamic banks in Malaysia should accommodate more profit and loss products in order to be more interest-free.

According to the estimation result shows that the spin-off policy doesn't have an impact on financing growth in Islamic banks resulted from spin-off. This implies that the spin-off policy is contained in the Act No. 21 of 2008 related to the article governing the separation is still need an improvement to accelerate the financing growth of Islamic banks resulted from spin-off.

These findings are inconsistent with that made by Al Arif ${ }^{11}$ that seeks to look at the effect of the spin-off policy on the growth of Islamic banking industry in Indonesia, which one of the purposes is to analyze the impact of spin-off policy on financing growth in Indonesian Islamic banking industry. In a previous study was using the independent variable in the form of a dummy variable separation, the level of financing problems (NPF), the value of the efficiency ratio (ROA), and the level of profitability (ROA). The results showed that all independent variables have a significant impact on financing growth on the Islamic banking industry in Indonesia.

Different results were obtained by Nasuha, which conducts research related to differences in the performance of Islamic business unit who decided to split (BNI Syariah, BRI Syariah, BJB Sharia, BSB, and Bank Victoria Sharia) one year before and one year after spin off by using the Wilcoxon Match Pairs test. The Wilcoxon Test shows that the performance difference between before and after the spin-off occurred on 3 variables, i.e. assets, financing, and Third Party Fund (TPF).

There are several arguments to explain why the spin-off policy doesn't have an impact on financing growth in Islamic banks resulted from spin-off. First, the operational cost of Islamic bank resulted from spin-off is higher than operational income, especially in earlier period of spin-off the operational efficiency values (BOPO) is very high. Therefore, the Islamic bank resulted

${ }^{10}$ Solarin Sakiru Adebola, , et.al. The Impact of Macroeconomic Variables on Islamic Banks Financing in Malaysia. (Research Journal of Finance and Accounting, Vol. 2, No. 4, 2011), p. 22-32

${ }_{11}$ M. Nur Rianto Al Arif. The Spin-off Impact to of Indonesian Islamic Banking Industry Growth. Working Paper. (Jakarta: UIN Syarif Hidayatullah Jakarta, 2014) 
from spin-off will be more careful in order not to add finance portfolio operating expenses. Second, Islamic banks resulted from spinoff still doing internal consolidation after the spin-off. Third, the Islamic banking network limitation, this is show on table 6 .

Table 6. The Islamic bank network

\begin{tabular}{lccc}
\hline \multicolumn{1}{c}{ Bank } & $\begin{array}{c}\text { Branch } \\
\text { Office }\end{array}$ & $\begin{array}{c}\text { Sub Branch } \\
\text { office }\end{array}$ & Cash Office \\
\hline BNI Sharia & 64 & 159 & 17 \\
BRI Sharia & 51 & 196 & 7 \\
BJB Sharia & 9 & 56 & 1 \\
Bukopin Sharia & 12 & 8 & 5 \\
Victoria Sharia & 8 & 11 & - \\
Panin Sharia & 7 & 5 & - \\
BCA Sharia & 8 & 6 & - \\
Maybank Sharia Indonesia & 1 & - & - \\
\hline
\end{tabular}

Source: Islamic banking statistics, Financial Service Authority

\section{Conclusion}

The estimation results to see the effect of spin-off policy on the financing growth in Islamic banks show that the spin-off dummy variable has no effect on the financing growth. Variables that influence in affecting the financing growth of Islamic commercial bank that result from spin-off on this study are third party funds and interest rate. This suggests that the higher thirdparty funds, the higher the amount of the financing of Islamic banks.

There are several arguments to explain why the spin-off policy doesn't have an impact on financing growth in Islamic banks resulted from spin-off. First, the operational cost of Islamic bank resulted from spin-off is higher than operational income, especially in earlier period of spin-off the operational efficiency values (BOPO) is very high. Therefore, the Islamic bank resulted from spin-off will be more careful in order not to add finance portfolio operating expenses. Second, Islamic banks resulted from spinoff still doing internal consolidation after the spin-off. Third, the Islamic banking network limitation. 


\section{REFERENCES}

Adebola, Solarin Sakiru, et.al. 2011. The Impact of Macroeconomic Variables on Islamic Banks Financing in Malaysia. Research Journal of Finance and Accounting, Vol. 2, No. 4.

Al Arif, M. Nur Rianto. 2014. The Spin-off Impact to of Indonesian Islamic Banking Industry Growth. Working Paper. Jakarta: UIN Syarif Hidayatullah Jakarta.

Ambarwati, Septiana. 2011. The Factors That Influence the Murabahah and Mudharabah Financing on Indonesian Islamic Commercial Banking. (Unpublished Thesis). Depok: Universitas Indonesia.

Asy'ari, Mohammad Hasyim. 2009. The Factors That Influence Islamic Bank's Financing. (Unpublished Thesis). Depok: Universitas Indonesia.

Bchini, B. 2012. Spin-off: Factor of Growth and Entrepreneurial Success: The Example of Tunisia. International Journal of Business and Social Science, Vol. 3, No. 12, June.

Chemmanur, T.J. \& A.Yan. 2004. A Theory of Corporate Spin-offs. Journal of Financial Economics, Elsevier, Vol. 72, Issue 2, May.

Chu, P.Y., et. al. 2010. Spin-off Strategies and Performance: A case study of Taiwan's Acer Group. Asian Business and Management, 2010, Vol. 9, 1.

Elfring, T. \& N.J. Foss. 1997. Corporate Renewal Through Internal Venturing and Spin-offs: Perspectives from Organizational Economics. Working Paper 97-7, Department of Industrial Economics and Strategy Copenhagen Business School.

Klepper, S. \& P. Thompson. 2010. Disaggrements and Intra-Industry Spinoffs. International Journal of Industrial Organization, Elsevier, vol. 28(5).

Nasuha, A. 2012. The Impact of Spin-off Policy on Islamic Bank Performance. Al-Iqtishad Journal, Vol. IV, No. 2.

Tubke, Alexander. Success Factors of Corporate Spin-Offs. New York: Springer. 